higher education will be run by the British civil service.

Mr Baker keeps saying that he has no intention of using the powers his bill will give him, in which case he will presumably volunteer amendments to the present text that will still the anxieties on this score that have been voiced so far. Academics might usefully bend their energies to devising suitable forms of words. The other structural weakness of the new arrangements is that they rely on the recruitment of a small army of successful business-people farsighted enough, and with sufficient spare time, to labour at the administration of the new system. It is for the British parliament to find out whether the supply of these people will meet the demand Mr Baker plans to create.

The pity is that the proposed reforms, as they are described, will not advance the most respectable of the British government's intentions - that of making the British labour force better suited to what the world will be like next century. Indeed, by further distracting academics (already too committee-bound) from the jobs for which they are employed, the process of reform will be in part self-defeating. The educational matters left untouched by the bill as it stands concern the ways in which students are to be prepared at school for higher education and the manner (and the length of time) of their careers in the tertiary sector. Although the participation of young people in Britain has risen (to 16 per cent), that is only half of the corresponding ratio in Japan. And while the government of France (see page 104) is just now wrestling with some of the problems on Mr Baker's agenda, no harm would come if the British parliament broke, on this occasion, with its habitual practice of supposing its own problems to be unique.

\section{Less to spend}

\section{The need to cut the US budget deficit will have significant consequences for research.}

THE pre-Christmas panic to reduce this year's federal budget deficit by at least the $\$ 23,000$ million required to avoid automatic cutting will bear significantly on the spending plans of the civilian agencies in Washington which support research. So much (see page 101) is now clear. Perhaps the greatest disappointment is that the National Science Foundation (NSF), offered at the beginning of 1987 the prospect of growing to twice its then size over five years, will fall significantly below that growth curve. It will be a matter of great concern to see whether the goal is shaded in the budget for the next fiscal year (beginning in October), now only a few days from publication. It will do the administration great credit if it does its best, at the beginning of the last of the financial years it can hope to markedly to influence, if it begs and borrows from elsewhere in the federal budget so as to give NSF a chance to resume its growth. There will be more honour in the history books (and more profit in the balance of external trade a few years from now) for a $\$ 10$ million spent on civil research than $\$ 100$ million on new weapons systems.

But nobody should pretend this will be easy. Next year's budget will be even tighter, while it is far too soon to tell whether the world's financial markets will allow the administration to get away with the modest further reduction planned for 1988-89. Even at the time of the month-long congressional haggle about deficit-reductions after the stock-market tumble of 19 October, it seemed plain that barely staying within the legal limits would not suffice. Events since then have confirmed that suspicion. On balance, there is a high chance that stability will not come about without a more marked reduction of spending. That is on the assumption that the administration will not voluntarily choose the best course of increasing taxes modestly. But that is a safe bet in an election year, but it is entirely possible that such a step may be forced upon it, even with so little time left to go before November.

\section{Are germ-lines special?} The conclusion that genetic manipulation of the germ-line must be outlawed may be too hasty.

THERE is a great risk that we shall all drift into a muddle over the prospect that genetic manipulation of the nuclei of human cells might be used as means of counteracting the inherited effects of genes that happen to be deleterious. In the United States, $\mathrm{Mr}$ Jeremy Rifkin continues his campaign for the sanctity of all species' germ-lines. The British government's white paper on the general subject of what is called the new embryology, likely soon to be followed by draft legislation, is just as explicit as $\mathrm{Mr}$ Rifkin; acknowledging that the prospects of germ-line genetic manipulation are remote, the white paper nevertheless says "It is a procedure which society would clearly regard as ethically unacceptable, and the Bill will prohibit it". Readers of Nature will have noted that Professor David Weatherall made much the same point $(331,13 ; 1988)$, in a comment on a paper from $\mathrm{Dr}$ Richard C. Mulligan and colleagues at the Whitehead Institute, when he said that germ-cell manipulation should not be applied to human beings "because it would alter the genetic make-up of subsequent generations". That, of course is true, and the opinion is widely held. But is interdiction justified on that ground alone?

In spite of all the valuable, if anticipatory, attention lavished on the study of genetic manipulation over the past few years, several important and ultimately practical questions have been ducked. One of these is precisely the distinction between the still remote treatment of inherited genetic diseases by manipulating the genes of somatic cells and the still more distant prospect of manipulating the genomes of early embryos so as to avoid the possibility that unwanted genetic diseases will emerge. Why does the British government suppose that to be a "procedure that society would regard as ethically unacceptable"? If, indeed, it were the case that such a technique might utterly remove from a family the risk of carrying genetic haemophilia (and there is at present not the vaguest notion of how that might be done), might there not be circumstances in which society would welcome the development? Royal families with haemophilia would no doubt have jumped at the technique.

The reason why it is commonly supposed otherwise is not, of course, that breaking the transmission within families of known deleterious genes would be unacceptable, but that it is easy to think of ways in which a technique for manipulating the genetics of the human germ line could have horrendous consequences, by design or from mere ignorance. Engineering families of people with looks of the kind qualifying them to be film stars would no doubt appeal to some, but would probably be unproductive and certainly a waste of time. The knowledge that the genetic component of IQ must certainly involve many genes would similarly not deter clever people from wishing to perpetuate their own kind. There are nightmares to be conjured out of the contrary possibility, that families of unintelligent or dependent people might be founded deliberately, although it is difficult to see what the benefits of that might be. Indeed, as a little reflection will show, it is very difficult to see how genetic manipulation of the human germ-line, supposing it is ever practical, could profitably be put to malign application.

Is it sensible, in the circumstances, that potentially beneficial uses should be set aside without discussion? In the still-brief history of the public discussion of the uses that may be made of new techniques in cell biology, great benefits have followed from people's willingness to consider the worst cases, and then to decide deliberately how they must be avoided. This is the spirit in which genetic manipulation has been, from the outset, approached. To follow a different course in this connection will have the effect of ensuring that those who may responsibly worry about what may emerge remain in ignorance, leaving the field to those who are less responsible. 